\title{
Bychkova Vladyslava
}

Kyiv National University of Technologies and Design (Kyiv)

Scientific supervisor - PhD Maria Chernets

\section{ENERGY AND ENVIRONMENTAL SECURITY}

Environmental security and energy sources are one of the main global problems nowadays. The depletion of natural resources is compounded by their highly inefficient use, which has truly disastrous consequences.

The most dangerous is air pollution caused by deforestation, emissions of industrial enterprises, means of transport and burning products of coal and oil. This leads not only to deterioration of air for all living things, but also to the appearance of the greenhouse effect.

Also nature suffers because of water and soil pollutions. They caused by massive discharge of industrial, agricultural and household waste into water flows and using of chemical fertilizers, pesticides and herbicides that accumulate in the tissues of plants and animals.

Besides, a huge global problem is depletion of natural resources. Firstly, nonrenewable fossil energy of biogenic origin - coal and oil - is being depleted. Currently, the ratio of world energy consumption is as follows: oil - 43\%, gas - $16 \%$, nuclear and hydropower $-15 \%$, combustible waste $-14 \%$, coal $-8 \%$, others $4 \%$ [2]. Secondly, relatively renewable resources such as soil and forests are being depleted. The soil cover suffers from erosion, as a result of which the fertile layer decreases. Destruction of tropical forests, which are one of the largest sources of oxygen for our planet, is catastrophic.

One of the most important questions about the world's reserves of natural resources is this: for how many years the world's reserves of oil, gas and other mineral resources will be enough for humanity. Some forecasts say about 20 years for oil and gas and 200 years for coal [2]. 
In the past decades scientists have been trying to find a solution of this problem, but there is still little agreement on the best set of actions required to reduce global dependency on greenhouse gas emissions and fossil fuels. The great hopes of scientists around the world are primarily associated with the development of alternative energy sources such as solar energy, wind energy, alternative hydropower, geothermal energy and biofuels. They may help us to save natural resources, to produce energy without damage for environment and prolong lifetime of our planet.

\section{REFERENCES}

1. Загрози навколишньому середовищу. [Електронний ресурс] Режим доступу: http://uchebnik-online.com/131/2166.

2. Проблема виснаження природних ресурсів і альтернативні джерела енергіï [Електронний ресурс] Режим достп: https://studopedia.su/3_46442_problema-istoshcheniya-prirodnih-resursov-ialternativnie-istochniki-energii.

3. Warwick McKibbin, Peter Wicoxen. 2007. "Energy and Environmental Security", In Brookings Institution. Top 10 Global Economic Challenges: An Assessment of Global Risks And Priorities. 